\title{
DECISION MAKING ON NITROGEN MANAGEMENT OF OAT (AVENA SATIVA) USING GRAIN YIELD POTENTIAL AND NITROGEN USE EFFICIENCY
}

\author{
Onur HOCAOGLU*, Mevlut AKCURA \\ ${ }^{1}$ Canakkale Onsekiz Mart University, Faculty of Agriculture, Department of Field Crops, Canakkale, \\ TURKEY \\ *Corresponding author: onurhocaoglu@comu.edu.tr
}

Received: 17.05 .2020

\begin{abstract}
While oat is a major cold-climate cereal in Marmara region of Turkey, little is known about the nitrogen use efficiencies (NUE) of Turkish oat cultivars. This research aims to evaluate NUE, grain yield, and several agronomic traits of 5 oat cultivars in 5 nitrogen applications doses. Field trials were conducted in the Canakkale, Turkey for two growing seasons where NUE, grain yield, plant height, panicle length, grain number per panicle, and grain weight per panicle were determined. Results of variance analysis indicated statistical significance for year, genotype, $\mathbf{N}$ dose, and Genotype $\mathbf{x} \mathbf{N}$ dose effects for all traits. New oat cultivars (Kahraman, Yeniceri, and Sebat) were found to have higher grain yield and NUE compared to the older cultivars (Chekota and Seydisehir). Grain yield response of each cultivar to the increasing $\mathbf{N}$ levels were further investigated with regression analysis and Princial Component Analysis (PCA) Biplot. Results suggested that Kahraman has the highest grain yield potential when Sebat and Yeniceri can be recommended for the higher $\mathrm{N}$ doses. We conclude that oat breeding efforts of the last decade may have contributed to higher NUE along with improving grain yield of oat cultivars in Turkey.
\end{abstract}

Keywords: Nitrogen Use Efficiency, N Management, Oat, PCA Biplot, Regression, Turkey

\section{INTRODUCTION}

Oat (Avena sativa) is an annual cold climate cereal that traditionally grown as a low input fodder crop in Turkey. Oat is believed to be discovered as a weed in wheat and barley fields in the Mediterranean basin, and the Middle east then became a valuable fodder crop, especially for horse feeding (Zwer, 2010; Arendt and Zannini, 2013). The popularity of oat decreased in the beginning of the 20 th century due to motor vehicles replacing horses in transportation, considerably reducing the demand for oat grain. Although oat is not likely to come back with all its former glory, its grain is rediscovered in the last decade for its potential to improve our diet: protein, oil and betaglucan contents of oat grain are reported to be remarkable (Braaten et al., 1994; Moreau and Kamal-Eldin, 2015; Wrigley, 2017).

In the last decade, many new oat varieties are registered in Turkey due to the efforts of Agricultural Research Institutes of Ministry of Agriculture and Forestry where oat landraces through Turkey's flora were collected, identified and implemented in breeding programs with the principle aim of improving grain yield and biomass (Dumlupinar et al., 2012; Ercan et al., 2016). In addition to high grain yield and lodging-resistant straw structures, these new cultivars were also often registered with the emphasis on their potential as a food crop (Kahraman et al., 2017). In this perspective, oat breeding of the last decade resembles the great achievements of wheat breeding from the 1950's: a high-input N strategy may now be also applicable to oat. Thus, the need arises to revisit the $\mathrm{N}$ management of oat cultivars. Use of $\mathrm{N}$ in higher doses on new cultivars may prove profitable. Still, the decision making about the quantity of $\mathrm{N}$ fertilizer will depend on both cultivar and the intended use (grains or fodder) and ultimately be an economical choice.

This research aimed to evaluate NUE, grain yield (GY), and several agronomic traits of five oat cultivars on varying $\mathrm{N}$ doses with the purpose of better understanding $\mathrm{N}$ management of Turkish oat cultivars in Canakkale conditions.

\section{MATERIALS AND METHODS}

Trials are conducted in the 2015-2016 and 2017-2018 growing seasons in the Unit of Agricultural Production and Research of COMU Faculty of Agriculture, Canakkale (Turkey). The material set consists of five Turkish oat varieties with varying characteristics: two conventional and three new oat cultivars (Table 1) were grown in five nitrogen doses $\left(0,5,10,15\right.$, and $\left.20 \mathrm{~kg} \mathrm{da}^{-1}\right)$. 
Further information about these cultivars are obtained from their corresponding registration institutions (Anonymous, $2019 \mathrm{a} ; \mathrm{b} ; \mathrm{c} ; \mathrm{d} ; \mathrm{e}$ ). Trials are laid out in split plot design with four replications where $\mathrm{N}$ doses were applied as the main plot effect. Main plots and replications were separated from each other by two meters to avoid $\mathrm{N}$ runoff (Pask et al., 2012). Sub-plots of each genotype were $6 \mathrm{~m}^{2}$, contained six plant rows with $0.2 \mathrm{~m}$ space inbetween and sown with the density of 400 plants $\mathrm{m}^{-2}$ (Sari,
2012; Dai et al., 2013). Trials were sown in different areas in the same facility each year, both of which were not cultivated in the previous year. Oat seeds were treated with insecticides to suppress the pest damage before germination (deltamethrin and imidacloprid in the first and second years, respectively). Broad-leaved weeds were controlled by herbicides (chlorsulfuron) when others were controlled by hand.

Table 1. List of oat cultivars and comparison of their agronomic characteristics published by their corresponding registered institutions

\begin{tabular}{lccccc}
\hline Cultivar Name & Yeniceri & Chekota* & Seydisehir & Sebat & Kahraman \\
\hline $\begin{array}{l}\text { Registered } \\
\text { institutions }\end{array}$ & $\begin{array}{c}\text { Bahri Dağdaş } \\
\text { International } \\
\text { Agricultural } \\
\text { Research Institute }\end{array}$ & $\begin{array}{c}\text { Transitional Zone } \\
\text { Agricultural } \\
\text { Research } \\
\text { Institute }\end{array}$ & $\begin{array}{c}\text { Bahri Dağdaş } \\
\text { International } \\
\text { Agricultural } \\
\text { Research Institute }\end{array}$ & $\begin{array}{c}\text { Private Sector- } \\
\text { Trakya Tarım ve } \\
\text { Vet. Tic. Ltd. } \\
\text { Sti. }\end{array}$ & $\begin{array}{c}\text { Trakya } \\
\text { Agricultural } \\
\text { Research } \\
\text { Institute }\end{array}$ \\
\hline Release Year & 2013 & 1986 & 2004 & 2011 & 2014 \\
\hline Height & Short & Long & Long & Short & Short \\
\hline $\begin{array}{l}\text { Agronomic } \\
\text { characteristics }\end{array}$ & Facultative & Winter & Facultative & Facultative & $\begin{array}{c}\text { Facultative - } \\
\text { Winter }\end{array}$ \\
\hline \multirow{2}{*}{ Use } & Early & Early & Semi - Early & Early \\
\cline { 2 - 6 } & $\begin{array}{c}\text { Resistant to } \\
\text { Lodging }\end{array}$ & Fedium resistant \\
to lodging & $\begin{array}{c}\text { Resistant to } \\
\text { Lodging }\end{array}$ & $\begin{array}{c}\text { Resistant to } \\
\text { Lodging }\end{array}$ \\
\cline { 2 - 6 } & $\begin{array}{c}\text { Fodder, biscuit } \\
\text { production }\end{array}$ & Fodder & Fodder & Fodder & $\begin{array}{c}\text { Fodder, biscuit } \\
\text { production, } \\
\text { food }\end{array}$ \\
\hline
\end{tabular}

*Seed production is no longer continued

Soil analysis results are presented in Table 2. According to these results, we decided that (especially considering soil $\mathrm{pH}$ and lime contents) diammonium phosphate (DAP) were the only suitable form of phosphorus fertilization where using other $\mathrm{P}$ fertilizers might have resulted in less $\mathrm{P}$ bioavailability in the soil and thereby affect the results (Muftuoglu, 2008; Anonymous, 2010). Hence, $8 \mathrm{~kg} \mathrm{da}^{-1} \mathrm{P}_{2} \mathrm{O}_{5}$ in the DAP form is applied prior to the sowing. Sum of unintentional application of $\mathrm{N}$ with DAP and natural soil $\mathrm{N}$ was accounted for the control $\left(\mathrm{N}_{0}\right)$ together. Ammonium nitrate $(\% 33)$ is used for nitrogen applications of $5,10,15$, and $20 \mathrm{~kg} \mathrm{da}^{-1}$ in three equal installments: one with the sowing, one by the beginning of stem elongation, and one by the beginning of ear emergence. Plant heights $(\mathrm{PH})$ of each plot were determined from the average heights of five random plants measured at the end of the flowering stage.

Table 2. Results of soil fertility analysis from separate trial areas of both years

\begin{tabular}{cllclllll}
\hline Years & Texture & $\begin{array}{l}\text { Saturation } \\
\text { Percentage } \\
(\%)\end{array}$ & pH & $\begin{array}{l}\text { Soluble } \\
\text { Salts } \\
(\mathbf{d S} / \mathbf{m})\end{array}$ & $\begin{array}{l}\text { Lime } \\
(\boldsymbol{\%})\end{array}$ & $\begin{array}{l}\text { Organic } \\
\text { Matter } \\
(\boldsymbol{\%})\end{array}$ & $\begin{array}{l}\text { Phosphorus } \\
\left(\mathbf{k g} \mathbf{P}_{2} \mathbf{O}_{5} / \mathbf{d a}\right)\end{array}$ & $\begin{array}{l}\text { Potassium } \\
(\mathbf{k g ~ K} \mathbf{O} / \mathbf{d a})\end{array}$ \\
\hline $2015-2016$ & $\begin{array}{l}\text { Sandy } \\
\text { clay loam } \\
\text { Clay } \\
\text { loam }\end{array}$ & 48,93 & 7,78 & 0,48 & 12,01 & 1,49 & 11,58 & 62,17 \\
\hline
\end{tabular}

Plant samples were acquired in harvest maturity by cutting one meter of plant rows from the ground in each plot that chosen randomly, which were weighted and

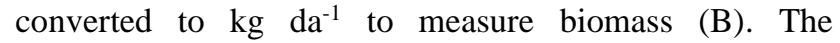
Outermost plant rows were excluded for plant samplings to avoid the border effect. A sub-collection of five random panicles from plant samples was used to determine thousand kernel weight (TKW) and panicle traits, including panicle length (PL), grain number per panicle (GNP), grain weight per panicle (GWP). Plots were harvested and threshed after the sample collection. Grain yield (GY) was calculated from the sum of the total weight of threshed grains of each plot, including the grain weight of samples and corrected to \%13 moisture. Lastly, nitrogen use efficiencies (NUE) of each plot were calculated in two steps. Firstly, grain yield difference is 
calculated by extracting the grain yield of each plot to the grain yield of $\mathrm{N}_{0}$ of the same cultivar in the same replication. Then, NUE of each plot $\left(\mathrm{kg} \mathrm{kg}^{-1}\right)$ is calculated by dividing the grain yield difference to the dose of $\mathrm{N}$ application, which reflected the grain yield increase per applied N (Duncan et al., 2018; Ciampitti and Vyn, 2012).

Results of two years of field trials were evaluated with ANOVA. Regression analysis was used to examine the different yield potential of each cultivar (Figure 6, Table 2) when the PCA Biplot method was used to display genotype $\mathrm{x}$ N dose interactions (JMP, 2016).

\section{RESULTS AND DISCUSSION}

One-way ANOVA results of traits nested in years showed statistically significant differences in all investigated traits for genotype, N Dose, and genotype $\mathrm{x} \mathrm{N}$ dose interactions (Table 3). In Table 3, differences between oat cultivars are most visible in thousand kernel weights (TKW) where the mean square of genotype effect surpasses all other factors. However, the mean square of the year effect was distinctively higher than others in nearly all other traits including grain yield (GY), plant height $(\mathrm{PH})$, grain number per panicle (GNP), grain weight per panicle (GWP) and nitrogen use efficiency (NUE). This is due to the varying environmental conditions of different years and is widely reported in the literature. In addition to the deviations observed in GY, yearly variation of NUE may also be susceptible to the changes of many other factors, including air humidity, temperature, and soil moisture. In cases of low humidity, high heat and high soil moisture, higher evaporation after anthesis may lead to the higher ammonia losses from the top of plants, which reduces NUE (Guttieri et al., 2017).

Table 3. ANOVA results of NUE, GY and agronomic traits of 5 oat cultivars

\begin{tabular}{|c|c|c|c|c|c|c|c|c|c|c|}
\hline \multirow{2}{*}{$\begin{array}{l}\text { Sources of } \\
\text { Variation }\end{array}$} & \multirow[b]{2}{*}{$D f$} & GY\# & PH\# & PL\# & GNP\# & GWP & B\# & \multirow[t]{2}{*}{ TKW\# } & \multirow[b]{2}{*}{ Df } & \multirow{2}{*}{$\begin{array}{l}\text { NUE\# } \\
M S\end{array}$} \\
\hline & & \multicolumn{6}{|c|}{ Mean Squares (MS) } & & & \\
\hline Year & 1 & $5071,30 * *$ & $206,29 * *$ & $65,36 * *$ & $293,25 * *$ & $9,22 * *$ & $1864,69 * *$ & $4,04 * *$ & 1 & $6,35 * *$ \\
\hline Replication (Year) & 6 & $68,69 * *$ & 2,05 & 3,63 & 2,45 & 0,05 & 894,97 & 0,17 & 6 & 0,58 \\
\hline Genotype & 4 & $1014,63 * *$ & $14,16 * *$ & $114,83^{* *}$ & $54,80 * *$ & $4,38 * *$ & $2124,94 * *$ & $12,45 * *$ & 4 & $2,91 * *$ \\
\hline Year x Genotype & 4 & $677,32 * *$ & $23,31 * *$ & $13,43 * *$ & $16,71 * *$ & $0,76^{* *}$ & $11022,69 * *$ & $0,11 * *$ & 4 & $4,44 * *$ \\
\hline Whole Plot Error & 24 & 6,45 & 0,28 & 0,74 & 0,29 & 0,03 & 135,85 & 0,04 & 24 & 0,01 \\
\hline N Dose & 4 & $2396,71 * *$ & $8,43 * *$ & $19,70 * *$ & $23,64 * *$ & $0,89 * *$ & $15861,31 * *$ & $0,49 * *$ & 3 & $0,67 * *$ \\
\hline Year x N Dose & 4 & $56,24 * *$ & $2,55 * *$ & $17,24 * *$ & $11,89 * *$ & $0,54 * *$ & $3705,15 * *$ & $0,82 * *$ & 3 & $0,25 * *$ \\
\hline Genotype x N Dose & 16 & $133,06 * *$ & $1,72 * *$ & $13,71 * *$ & $3,86 * *$ & $0,56 * *$ & $953,82 * *$ & $0,47 * *$ & 12 & $0,10 * *$ \\
\hline $\begin{array}{l}\text { Year x Genotype } x \\
\text { N Dose }\end{array}$ & 16 & $117,38 * *$ & $3,29 * *$ & $7,09 * *$ & $3,24 * *$ & $0,35 * *$ & $1252,77 * *$ & $0,27 * *$ & 12 & $0,12 * *$ \\
\hline Error & 120 & 4,04 & 0,12 & 0,35 & 0,18 & 0,01 & 70,34 & 0,01 & 90 & 0,05 \\
\hline Total & 199 & & & & & & & & 159 & \\
\hline$r^{2}$ & 0,98 & & & & & & & & 0,94 & \\
\hline$\sqrt{ } \mathrm{MSE}$ & 20,09 & & & & & & & & 2,14 & \\
\hline
\end{tabular}

$*$ and ${ }^{* *}$ stands for the significance levels 0.05 and 0.01, respectively. \#:Values are divided to 100. Df: Degree of freedom, MSE: Mean square error, GY: Grain yield, PH: Plant height, PL: Panicle length, GNP: Grain number per panicle, GWP: Grain weight per panicle, B: Biomass, TKW: Thousand kernel weight, NUE: Nitrogen use efficiency.

Average results of two years for all traits are transformed in percentiles for easier evaluation and presented separately for each cultivar and $\mathrm{N}$ level in Figures $1-5$. Results indicated that changes in the agronomic traits in response to the increases of $\mathrm{N}$ doses differed for each genotype. New cultivars (Kahraman, Sebat, and Yeniceri) demonstrated a higher response to the $\mathrm{N}$ fertilization in terms of grain yield, panicle traits, and biomass compared to the old cultivars (Chekota and Seydisehir). This is expected since the ability of new cultivars to respond better to the increasing levels of $\mathrm{N}$ is well documented and is a direct result of plant breeding (Muurinen et al., 2006; Ortiz-Monasterio et al., 1997; Ciampitti and Vyn, 2012; Maral et al., 2012). In general, new oat cultivars had an apparent advantage of utilizing higher doses of $\mathrm{N}$ more efficiently and provided higher grain yields and panicle weights at the 15 and $20 \mathrm{~kg} \mathrm{da}^{-1} \mathrm{~N}$ $\left(\mathrm{N}_{15}\right.$ and $\mathrm{N}_{20}$, respectively). However, different agronomic characteristics of the new cultivars were also remarkable.
In Figure 2a through 2e, panicle and thousand kernel weights of Kahraman gradually responds to the increasing $\mathrm{N}$ doses when grain number per panicles of Sebat and Yeniceri, other two cultivars with high grain yields were more responsive to the rising level of $\mathrm{N}$ (Figures $3 \mathrm{a}$ to $3 \mathrm{e}$ and $5 \mathrm{a}$ to $5 \mathrm{e}$ ). These findings suggest that the panicle weights of new cultivars may be increasing with relation to TKW or (Kahraman) or GNP (Sebat and Yeniceri), which depends on the cultivar.

Grain yield responses of five oat cultivars are presented in Figure 6. Lowest yields for all cultivars were recorded at $0 \mathrm{~kg} \mathrm{da}^{-1} \mathrm{~N}$ level when maximum yields were achieved at $15 \mathrm{~kg} \mathrm{da}^{-1}$ for Chekota, Seydisehir, and Yeniceri and $20 \mathrm{~kg} \mathrm{da} \mathrm{da}^{-1}$ for Kahraman and Sebat. Furthermore, the advantages of new cultivars became more apparent as $\mathrm{N}$ doses increased since Sebat, Kahraman, and Yeniceri outperformed Chekota and Seydisehir in 15 and $20 \mathrm{~kg} \mathrm{da}^{-1}$ doses of N (Figure 6). 


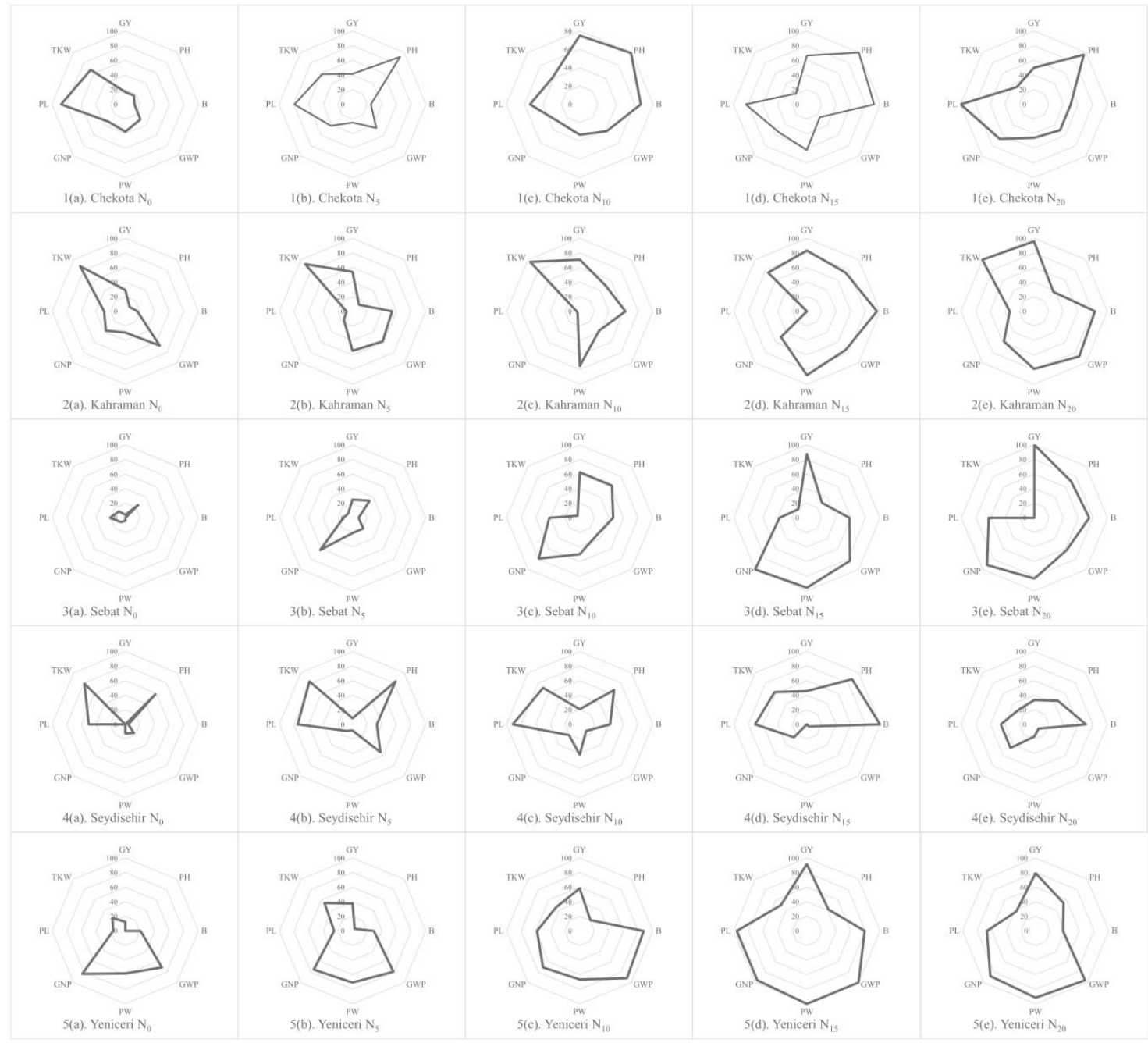

Figures 1-5. Agronomic responses of oat cultivars to increasing levels of N.

Average results of two experiment years were transformed into the scale of 100 with the highest value for each trait were fixed to 100 .



Figure 6. Grain yield responses of oat cultivars to different $\mathrm{N}$ levels with regression lines 
Average grain yield increases of all oat cultivars fit best to the quadratic regression except for Kahraman, grain yield $-\mathrm{N}$ dose relation of which can be better explained by linear regression (Table 4). There are reports that both quadratic (Mantai et al., 2015; Lollato et al., 2019) and linear regression models (Maral et al., 2013) can be used to explain grain yield $\mathrm{x} \mathrm{N}$ dose relationships. This is probably due to whether a given genotype reaches to its maximum yield within the applied $\mathrm{N}$ spectrum: in case of Kahraman, a linear increase of grain yield continued until the maximum $\mathrm{N}$ dose, indicating that 20 $\mathrm{kg} \mathrm{da}^{-1} \mathrm{~N}$ was not sufficient to reveal the maximum potential yield of Kahraman. Therefore, we conclude that in our study, Kahraman has the highest grain yield potential. Equations of quadratic regression models allow us to calculate the potential maximum grain yields of other cultivars since a quadratic equation is essentially a parabola with the general function of $f(x)=a x^{2}+b x+c$.
Axis of symmetry of a parabola can be calculated with the formula of -b/2a. In our case, the axis of symmetry of each quadratic equation coincides with the highest potential yield of given oat cultivar and its corresponding $\mathrm{N}$ dose, allowing us to compare the other cultivars by their grain yield potential (Kim et al., 2019). In Table 2, Sebat has the highest grain yield potential of $820.18 \mathrm{~kg} \mathrm{da}^{-1}$ that is theoretically attainable at $48.08 \mathrm{~kg} \mathrm{da}^{-1} \mathrm{~N}$ level, followed by another new cultivar, Yeniceri with $604.92 \mathrm{~kg} \mathrm{da}^{-1}$ in $21.22 \mathrm{~kg} \mathrm{da}^{-1} \mathrm{~N}$ (Table 4). The yield potential of older cultivars was found to be relatively lower. Chekota had the highest potential grain yield of $529.36 \mathrm{~kg} \mathrm{da} \mathrm{da}^{-1}$ corresponding to $12.5 \mathrm{~kg} \mathrm{da}^{-1} \mathrm{~N}$. Finally, Seydisehir cultivar had the lowest grain yield potential in our study. The theoretical highest grain yield of Seydisehir is found $466.06 \mathrm{~kg} \mathrm{da}^{-1}$ at the $23 \mathrm{~kg} \mathrm{da}^{-1} \mathrm{~N}$.

Table 4. Regression analysis of oat cultivars with potential maximum yields

\begin{tabular}{lccccc}
\hline Cultivar & Regression formula & $\begin{array}{c}\text { Regression } \\
\text { Type }\end{array}$ & $\mathbf{R}^{\mathbf{2}}$ & $\begin{array}{c}\text { Maximum yield } \\
(\mathbf{k g} / \mathbf{d a})\end{array}$ & $\begin{array}{c}\text { N level for maximum } \\
\text { yield (kg N/da) }\end{array}$ \\
\hline Chekota & $\mathrm{y}=-0,8443 \mathrm{x}^{2}+21,132 \mathrm{x}+396,84$ & Quadratic & 0,9369 & 529,36 & 12,5 \\
Kahraman & $\mathrm{y}=9,5283 \mathrm{x}+445,53$ & Linear & 0,9976 & & 48,08 \\
Sebat & $\mathrm{y}=-0,2012 \mathrm{x}^{2}+19,349 \mathrm{x}+353,75$ & Quadratic & 0,9852 & 820,18 & 23 \\
Seydisehir & $\mathrm{y}=-0,2472 \mathrm{x}^{2}+11,372 \mathrm{x}+334,26$ & Quadratic & 0,8966 & 466,06 & 21,22 \\
Yeniceri & $\mathrm{y}=-0,5215 \mathrm{x}^{2}+22,13 \mathrm{x}+370,15$ & Quadratic & 0,9116 & 604,92 & \\
\hline
\end{tabular}

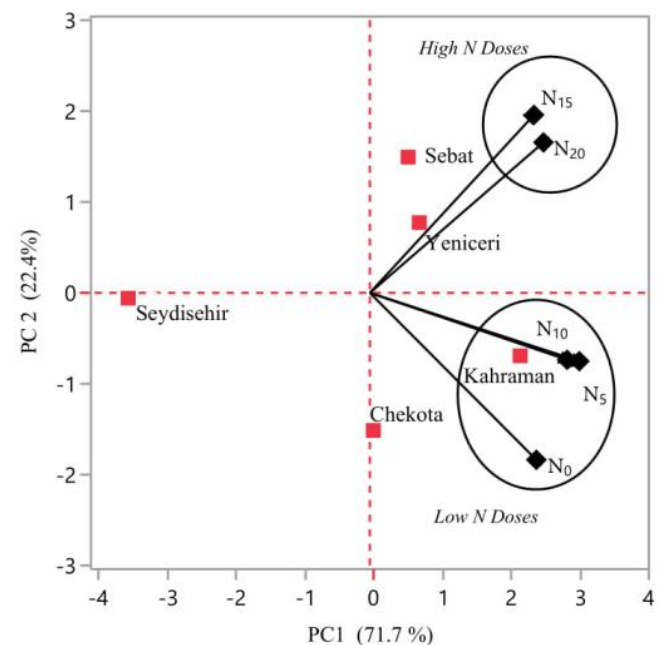

Figure 7. PCA Biplot of oat cultivars grown in different $\mathrm{N}$ regimes.

Principal component analysis (PCA) biplot is also a useful tool to evaluate varying genotype performances over a series of environments or applications (Ilker et al., 2011; Langeroodi et al., 2015). PCA Biplot of grain yields of oat cultivars in various $\mathrm{N}$ fertilizer doses can be used to evaluate Genotype x N Dose interactions. In Figure 7, the first and second principal components accounted for the $\% 94,1$ of the total variation. In PCA Biplot, the proximity between any two objects is a measure of their relationships (Yan, 2014). Therefore, according to the grain yield responses of oat cultivars in this study, $\mathrm{N}$ doses were divided into two groups: first group consists of 15 and $20 \mathrm{~kg} \mathrm{da}^{-1} \mathrm{~N}$ when the second group included 0,5 and $10 \mathrm{~kg} \mathrm{da}^{-1} \mathrm{~N}$, indicating a distinction between high and low $\mathrm{N}$ doses (Figure 7). This allows for the recommendation of specific cultivars for high and low $\mathrm{N}$ input because in some cases, low $\mathrm{N}$ input might be a valid strategy in oat cultivation. In southern parts of Marmara region, including Canakkale province, oat is not grown as the main source of income by many smallholders. Occasionally, oat is grown to make use for marginal fields to generate additional fodder or hay for the livestock, in which case the minimum costs of inputs such as $\mathrm{N}$ fertilizer might be desired. Our results showed that Kahraman could be recommended for such use since it outperformed other cultivars by yielding higher in lower $\mathrm{N}$ doses (Figures 1-5), hence positioned near to the second group in PCA Biplot where lower $\mathrm{N}$ doses are also present (Figure 7). Although not as high yielding as Kahraman, Chekota is another cultivar that would suit better to the low-input oat farming. On the other hand, grain yields of Sebat and Yeniceri responded to high $\mathrm{N}$ doses better than other cultivars and positioned near to the higher $\mathrm{N}$ doses. Lastly, Seydisehir's position on PCA Biplot further confirms that Seydisehir cannot be recommended for any $\mathrm{N}$ doses for any purposes (Figure 7) because it has the lowest grain yield average of all varieties in every $\mathrm{N}$ level (Figure 6). 


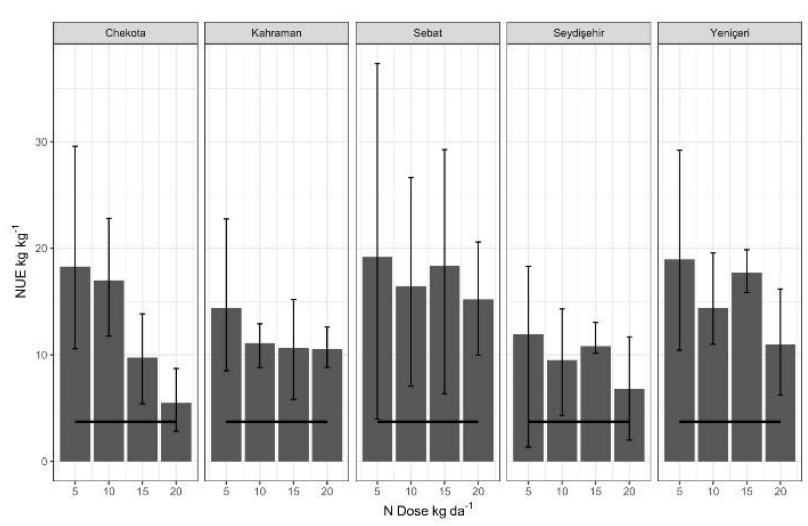

Figure 8. NUE averages of oat cultivars with the horizontal line representing the $\mathrm{Fc} / \mathrm{Gp}$ of 2018

Our calculations of NUE suggests that cultivar selection is an essential part of $\mathrm{N}$ management (Figure 8). The highest NUE for each genotype were observed when fertilizer is used minimum $\left(5 \mathrm{~kg} \mathrm{da}^{-1} \mathrm{~N}\right)$, which is expected since NUE is known to decrease as $\mathrm{N}$ fertilizer usage increases (Delogu et al., 1998; Fageria ve Baligar, 2003; Krobel et al., 2012). A gradual decrease of NUE with increasing $\mathrm{N}$ doses indicates that grain yield of oat cultivars does not respond proportionally to the increasing levels of N. Previous research remarked that in wheat, nitrogen utilization is negatively affected as $\mathrm{N}$ doses increased (Rasmussen et al., 2015). It is logical to assume that plant $\mathrm{N}$ uptake is restricted in $\mathrm{N}$-rich environments. This may be due to many factors. $\mathrm{N}$ uptake in higher $\mathrm{N}$ doses may be source-limited or simply restricted by increasing $\mathrm{N}$ losses from the plant surface or soil (Lemaire and Gastal, 2009). Regardless of how, choosing $\mathrm{N}$ efficient cultivars is a way to increase NUE since the genotype effect on NUE was significant (Table 3). In Figure 2, new oat cultivars (Kahraman, Sebat, and Yeniceri) responded to $\mathrm{N}$ fertilizer better than Chekota and Seydisehir by having higher NUE, especially in higher $\mathrm{N}$ doses. Since our approach to calculate NUE as the net increase of the grain yield per applied fertilizer, comparing NUE with the grain prices of oat and $\mathrm{kg}$ cost of $\mathrm{N}$ would reveal the marginal cost of $\mathrm{N}$ fertilizer for each application (Please see the Agronomic Efficiency concept in Mengel ve Kirkby, 2001 for more information). In 2018, for example, each $\mathrm{kg} \mathrm{N}$ of urea cost $3.62 \mathrm{TL}$ (Fertilizer cost, $\mathrm{Fc}$ ) when the average $\mathrm{kg}$ price of oat (Grain price, Gp) was only 0.97 TL (TURKSTAT, 2020; Ministry of Agriculture and Forestry of Turkey, 2020). Therefore, the ratio of the fertilizer cost to the grain price of oat $(\mathrm{Fc} / \mathrm{Gp})$ for 2018 is calculated as 3.73, which remarks the absolute minimum NUE for oat for Turkey in 2018 where the revenue of oat grain is equal to the fertilizer costs. All applications had higher NUE than 3.73 $\mathrm{kg} \mathrm{kg}^{-1}$ when Chekota and Seydisehir grown in $20 \mathrm{~kg} \mathrm{da}^{-1}$ $\mathrm{N}$ had NUE averages that fall just above the $\mathrm{Fc} / \mathrm{Gp}$ line (Figure 8). Since this calculation excludes other numerous expenses of a farm other than fertilizer costs, cultivating oat for its grain is an absolute loss if NUE is equal to the
Fc/Gp. In reality, NUE should be much higher than Fc/Gp to indicate a clear profit. This means that in given conditions, growing older oat cultivars for grain with using $20 \mathrm{~kg} \mathrm{da}^{-1} \mathrm{~N}$ would barely cover for the prices of used $\mathrm{N}$ fertilizer, therefore likely to cause financial losses when other expenses and risks are considered. On the other hand, Sebat and Yeniceri would have been much more profitable in higher $\mathrm{N}$ doses due to their higher NUE (Figure 8). Thus, choosing the right cultivar with high NUE is trivial for the financial gain.

In conclusion, results indicate that based on their response to $\mathrm{N}$ fertilizers, oat genotypes used in this study can be divided into new (Kahraman, Sebat, Yeniceri) and older (Seydisehir, Chekota) cultivars. Our findings agree with previous studies that recent cultivars tend to surpass older ones by having higher grain yield and NUE (Kant et al., 2010; Muurinen et al., 2006; Ortiz-Monasterio et al., 1997; Ciampitti et al., 2012). In addition, based on their high NUE and the results of regression analysis, new cultivars are found to be more responsive to the higher $\mathrm{N}$ doses. Highest recorded grain yields of field trials are observed in 15 and $20 \mathrm{~kg} \mathrm{da}^{-1} \mathrm{~N}$ level from Yeniceri, Kahraman and Sebat. In addition, Kahraman can also be characterized by its high TKW and its ability to adapt better to low $\mathrm{N}$ doses when also having the highest yield potential of all oat cultivars. In the case of high $\mathrm{N}$ doses, Yeniceri and Sebat came forward because they yield less than Kahraman in $0 \mathrm{~kg} \mathrm{da}^{-1} \mathrm{~N}$, which makes their response to the increasing $\mathrm{N}$ levels more remarkable. Therefore, although all three new cultivars would yield high in high $\mathrm{N}$ doses, PCA Biplot and NUE results point out using Sebat and Yeniceri as the best choices in N-rich environments. Although, significant year $\mathrm{x}$ genotype interaction in NUE and a limited number of genotypes of our study should be noted. More research on a wider set of oat genotypes will provide a decisive view of the status of NUE in oat breeding.

In terms of managing $\mathrm{N}$, several aspects should be considered. Farmers main consideration should be the economic aspect of using $\mathrm{N}$ fertilizer for the optimum gain. This means that $\mathrm{N}$ fertilizers should be applied timely and properly with carefully adjusted doses while keeping in mind that avoiding the excessive use of fertilizers is not only a matter of economy but also essential to prevent $\mathrm{N}$ pollution. Improving NUE in crops, without doubt, is one of the main challenges of plant breeding. Nevertheless, the real achievement for the future of agriculture will be engineering sustainable and environmental-friendly solutions to meet the increasing food demand of our world - that will certainly require a more careful $\mathrm{N}$ management.

\section{ACKNOWLEDGMENTS}

This research derived from a part of the $\mathrm{PhD}$ thesis of Onur HOCAOGLU and funded by the Scientific Research Projects Coordination Unit of Canakkale Onsekiz Mart University (COMU BAP) under the project number FDK2016-935. 


\section{LITERATURE CITED}

Anonymous. 2010. In: Utah Fertilizer Guide. Editors: James D. F., Topper K. F. Utah State University Cooperative Extension.

Anonymous. 2019a. Cultivars. Transitional Zone Agricultural Research Institute.

https://arastirma.tarimorman.gov.tr/gktaem/Belgeler/Tescilli\%20 Ceșitlerimiz/Yulaf/checota.pdf (Accessed March 12, 2019. In Turkish).

Anonymous. 2019b. Yeni Yulaf Cesidimiz Yeniceri. Bahri Dağdas International Agricultural Research Institute. https://arastirma.tarimorman.gov.tr/bahridagdas/Duyuru/7/Y eni-Yulaf-Cesidimiz-Yeniceri (Accessed March 12, 2019. In Turkish).

Anonymous. 2019c. Cultivars catalouge. Bahri Dagdas International Agricultural Research Institute.

https://arastirma.tarimorman.gov.tr/bahridagdas/Belgeler/Katalo g.pdf (Accessed March 12, 2019. In Turkish).

Anonymous. 2019d. Cultivars. Trakya Tarim Offical Website. http://www.trakyatarim.com/cesitler/YULAF/4 (Accessed March 12, 2019. In Turkish).

Anonymous. 2019e. Cultivars. Trakya Agricultural Research Institute. https://arastirma.tarimorman.gov.tr/ttae (Accessed March 12, 2019. In Turkish).

Arendt, E.K., E. Zannini. 2013. Oats, In: Cereal grains for the food and beverage industries, . Arendt E., Zannini E., Eds., Woodhead Publishing Series in Food Science, Technology and Nutrition, Cambridge, UK, pp. 243-283.

Braaten, J.T., P.J. Wood, F.W. Scott, M.S. Wolynetz, M.K. Lowe, P. Bradley-White, M.W. Collins. 1994. Oat betaglucan reduces blood cholesterol concentration in hypercholesterolemic subjects. European journal of clinical nutrition. 48(7): 465-474.

Ciampitti, I.A. and T.J. Vyn. 2012. Physiological perspectives of changes over time in maize yield dependency on nitrogen uptake and associated nitrogen efficiencies: A review. Field Crops Research 133: 48-67.

Dai, X., X. Zhou, D. Jia, L. Xiao, H. Kong, M. He. 2013. Managing the seeding rate to improve nitrogen-use efficiency of winter wheat. Field Crops Research 154: 100109.

Delogu, G., L. Cattivelli, N. Pecchioni, D. De Falcis, T. Maggiore, A.M. Stanca. 1998. Uptake and agronomic efficiency of nitrogen in winter barley and winter wheat. European Journal of Agronomy 9(1): 11-20.

Duncan, E.G., C.A. O’Sullivan, M.M. Roper, J.S. Biggs, M.B. Peoples. 2018. Influence of co-application of nitrogen with phosphorus, potassium and sulphur on the apparent efficiency of nitrogen fertiliser use, grain yield and protein content of wheat. Field crops research 226: 56-65.

Dumlupinar, Z., A. Tekin, S. Herek, A. Tanrikulu, T. Dokuyucu, A. Akkaya. 2012. Evaluating Some Turkish Originated Oat Genotypes for Some Agronomic Traits. Turkish Journal of Agriculture-Food Science and Technology 5(7): 763-772.

Ercan, K., A, Tekin, S. Herek, A. Kurt, E. Kekec, M.F. Olgun, T. Dokuyucu, Z. Dumlupinar, A. Akkaya. 2016. Performance of Local Oat Lines in Kahramanmara Conditions. KSU J. Nat. Sci. 19(4): 438-444 (In Turkish).

Fageria, N.K. and V.C. Baligar. 2003. Methodology for evaluation of lowland rice genotypes for nitrogen use efficiency. Journal of Plant nutrition 26(6): 1315-1333.

Guttieri, M. J., K. Frels, T. Regassa, B.M. Waters, P.S. Baenziger. 2017. Variation for nitrogen use efficiency traits in current and historical great plains hard winter wheat. Euphytica 213(4), 87.
Ilker, E., H. Geren, R.,Unsal, I. Sevim, F. A. Tonk, M. Tosun. 2011. AMMI-biplot analysis of yield performances of bread wheat cultivars grown at different locations. Turkish Journal of Field Crops 16(1): 64-68.

JMP, 2016. JMP® Version 13.2. SAS Institute Inc., Cary, NC, 1989-2019.

Kahraman, T., C. Kurt, A. Seis Subasi, T. Özderen, O. Yıldı, C. Buyukkileci, T. Sanal. 2017. Determination of Oat (Avena sativa L.) Genotypes Suitable for Human Nutrition in Trakya-Marmara Region. Journal of Central Research Institute for Field Crops 26 (Special Issue): 105-111 (In Turkish).

Kant, S., Y.M. Bi, S.J. Rothstein. 2010. Understanding plant response to nitrogen limitation for the improvement of crop nitrogen use efficiency. Journal of experimental Botany 62(4), 1499-1509.

Kim, G.W., J., Gutierrez-Suson, P.J., Kim. 2019. Optimum N rate for grain yield coincides with minimum greenhouse gas intensity in flooded rice fields. Field Crops Research 237: 23-31.

Krobel, R., C.A., Campbell, R.P., Zentner, R., Lemke, R.L., Desjardins, Y, Karimi-Zindashty. 2012. Effect of N, P and cropping frequency on nitrogen use efficiencies of spring wheat in the Canadian semi-arid prairie. Can. J. Plant Sci. 92:141-154.

Langeroodi, A.R.S. 2015. Sunflower and soil response to seven years of tillage, residue management and nitrogen fertilizer. Turkish Journal of Field Crops 20(2):194-202.

Lemaire, G., F., Gastal. 2009. Quantifying crop responses to nitrogen deficiency and avenues to improve nitrogen use efficiency. In Crop physiology: Applications for genetic improvement and agronomy (pp. 171-211). Academic Press San Diego.

Lollato, R.P., B.M. Figueiredo, J.S. Dhillon, D.B. Arnall, W.R. Raun. 2019. Wheat grain yield and grain-nitrogen relationships as affected by $\mathrm{N}, \mathrm{P}$, and $\mathrm{K}$ fertilization: $\mathrm{A}$ synthesis of long-term experiments. Field Crops Research 236: 42-57.

Mantai, R.D., J.A.G. da Silva, E.G. Arenhardt, T.G. Heck, A.T.Z.R. Sausen, C.A.M.B. Kruger, A.M. Cardoso, C.J.G. Neto, D.K. Krysczun. 2015. The effect of nitrogen dose on the yield indicators of oats. African Journal of Agricultural Research 10(39): 3773-3781.

Maral, H., Z. Dumlupinar, T. Dokuyucu, A. Akkaya. 2012. Impact of genotype and nitrogen fertilizer rate on yield and nitrogen use by oat (Avena sativa L.) in Turkey. Turkish Journal of Field Crops 17(2):177-184.

Maral, H., Z. Dumlupinar. T. Dokuyucu, A. Akkaya. 2013. Response of six oat (Avena sativa L.) cultivars to nitrogen fertilization for agronomical traits. Turkish Journal of Field Crops 18(2): 254-259.

Mengel, K., E.A. Kirkby, H. Kosegarten, T. Appel. 2001. Nitrogen. In Principles of Plant Nutrition (pp. 397-434). Springer, Dordrecht, Netherlands.

Ministry of Agriculture and Forestry of Turkey, 2020. Plant Nutrition Statistics. https://www.tarimorman.gov.tr/Konular/BitkiselUretim/Bitki-Besleme-ve-Tarimsal-Teknolojiler/BitkiBesleme-Istatistikleri (Assessed May 20, 2020). In Turkish.

Moreau, R., A. Kamal-Eldin (Eds.). 2015. Gourmet and healthpromoting specialty oils. Elsevier, Netherlands.

Muurinen, S., G.A. Slafer, P. Peltonen-Sainio. 2006. Breeding effects on nitrogen use efficiency of spring cereals under northern conditions. Crop Science 46(2): 561-568.

Muftuoglu, N.M. 2008. Basic Principles of Fertilization. Canakkale Onsekiz Mart University Publication No: 70. ISBN: 978-975-8100-76-7 (In Turkish). 
Ortiz-Monasterio, R., K.D. Sayre, S. Rajaram, M. McMahon. 1997. Genetic progress in wheat yield and nitrogen use efficiency under four nitrogen rates. Crop Science 37(3): 898-904.

Pask, A.J.D., R. Sylvester-Bradley, P.D. Jamieson, M.J. Foulkes. 2012. Quantifying how winter wheat crops accumulate and use nitrogen reserves during growth. Field Crops Research 126:104-118.

Rasmussen, I.S., D.B. Dresbøll, K. Thorup-Kristensen. 2015. Winter wheat cultivars and nitrogen $(\mathrm{N})$ fertilizationeffects on root growth, $\mathrm{N}$ uptake efficiency and $\mathrm{N}$ use efficiency. European Journal of Agronomy 68:38-49.

Sari, N. 2012. The Relationships between yield and yield components of oat (Avena sativa L.). M.Sc. Thesis, Department of Field Crops, Adnan Menderes University,
Aydın. https://tez.yok.gov.tr/UlusalTezMerkezi (Assessed 10 December, 2018).

TURKSTAT 2020. http://www.turkstat.gov.tr/ (Assessed May 20, 2020).

Wrigley, C. 2017. Cereal-Grain Morphology and Composition, In: Woodhead Publishing Series in Food Science, Technology and Nutrition, Cereal Grains (Second Edition), Ed. Wrigley, C., Batey, I. And Miskelly, D., Woodhead Publishing (pp. 55-87).

Yan, W. 2014. Crop variety trials: Data management and analysis. John Wiley \& Sons. ISBN:9781118688649.

Zwer, P. 2010. Oats: characteristics and quality requirements. In: Cereal Grains Ed. Wrigley, C., Batey, Woodhead Publishing Series in Food Science, Technology and Nutrition, CRC Press, UK (pp. 163-182). 